\title{
KARAKTERISTIK MATERIAL LOGAM 10 CENT HONGKONG DENGAN METODE XRD
}

\author{
Sri Wuryanti \\ Jurusan Teknik Konversi Energi - Politeknik Negeri Bandung \\ E-mail:sriwuryanti.lamda@gmail.com
}

\begin{abstract}
Abstrak
Karakteristik material bertujuan untuk bisa memahami dan memanfaatkan material dengan optimal yakni mengetahui dengan jelas struktur mikro maupun struktur makro dari material tersebut. Untuk mendapatkan informasi tentang struktur mikro salah satunya dapat dilakukan dengan metode analitik karakterisasi material menggunakan metode X-ray Difraction (XRD) untuk memodelkan jenis senyawa, prosentase senyawa dan karakteristik kristalografinya. Setelah diperoleh data-data, dilakukan pengolahan data hasil pengujian dengan software database pendukung Automatic Powder Difraction (APD) untuk melakukan fitting dari pola difraksi yang dihasilkan oleh XRD. PC-PDFWIN merupakan software database crystal yang terdapat pada International Crystal Difraction Data (ICDD), serta Match V1.9 yang merupakan software database crystal yang terdapat pada IUCr/COD/AMCSD. Untuk menentukan phasa atau senyawa yang terkandung dalam material secara tepat dilakukan analisa dengan GSAS+EXPGUI sebagai software analisis yang lebih akurat. Dari hasil pengujian diperoleh komposisi logam 10 cent Hongkong mengandung unsur Cu dan $\mathrm{Zn}$.
\end{abstract}

Kata Kunci: APD, XRD, PC-PDWIN, Match V1.9

\section{PENDAHULUAN}

Sekitar 95\% dari semua bahan padatan dapat dideskripsikan sebagai kristalin. Ketika sinar-x berinteraksi dengan senyawa kristalin (fasa), maka akan didapatkan pola difraksi. Sinar-X yang jatuh pada permukaan bidang kristal suatu material akan dihamburkan sesuai dengan komposisi atau jenis kristal tersebut. Pola hamburan (difraksi) sinar-X merupakan karakteristik masing-masing senyawa yang tidak tergantung satu sama lain. Panjang gelombang sinar-X yang digunakan untuk $X$ ray Difraction (XRD) berkisar antara 0,5 $2,5 \AA$.

Sinar X merupakan sinar hasil tumbukan antara elektron kecepatan tinggi yang dibangkitkan oleh filamen tusten dengan logam target. Logam target umumnya memakai kobalt dan tembaga. Komponen utama XRD, yaitu :

a. Sumber elektron (katoda) berupa filamen tungsten

b. Tegangan tinggi untuk mempercepat electron

c. Logam target (anoda), logam umumnya terbuat tembaga atau kobalt.

Hasil difraksi akan menggambarkan pola difraksi yang berupa spektrum karakteristik suatu sampel kristalin. Untuk menentukan phasa atau senyawa yang terkandung dalam material secara tepat dilakukan analisa dengan GSAS+EXPGUI. Untuk menjalankan program GSAS diperlukan beberapa tahapan dan sofware antara lain :

a.Perkiraan senyawa yang terkandung di dalam sampel

b.Space group dari kristal dan parameter kisi

c.Posisi atom dari kristal

d.Software program konversi Bella V2_12

e.Software GSAS + EXPGUI

\section{METODE PENELITIAN}

a.Persiapkan sampel koin

Cuci koin 10 cent Hongkong dengan cairan pembersih ethanol untuk menghindari adanya kontaminasi dengan material lain.

b.Pengujian sampel koin

- Letakkan sampel koin pada penjepit sampel bed

- Ukur posisi koin tepat pada garis tengah alat ukur sampel standart, apabila posisi sampel terlalu kecil dan tidak dapat dijepit, letakkan sampel pada lilin yang telah tersedia atau pergunakan alat bantu lain seperti kaca sampel.

- Kondisi Operasi Start angle ( $\left.{ }^{\circ} 2 \theta\right)$ : 20.010 dan End angle ( $\left.{ }^{\circ} 2 \theta\right): 89.970$ 


\section{HASIL DAN PEMBAHASAN}

\section{Analisa XRD ( $X$-ray diffraction)}

Dari percobaan XRD sampel koin 10 cent Hongkong akan didapatkan hasil pengujian berupa sudut $2 \theta$ dan intensitas dengan puncak tertinggi berada di sudut $52.24^{\circ}$ dan $77.065^{\circ}$, selanjutnya dengan menggunakan software Bella V2_12 data yang dikeluarkan oleh software APD pada peralatan XRD Philips PW3710 di reproduksi pola difraksinya seperti terlihat pada grafik1dan grafik 2 .

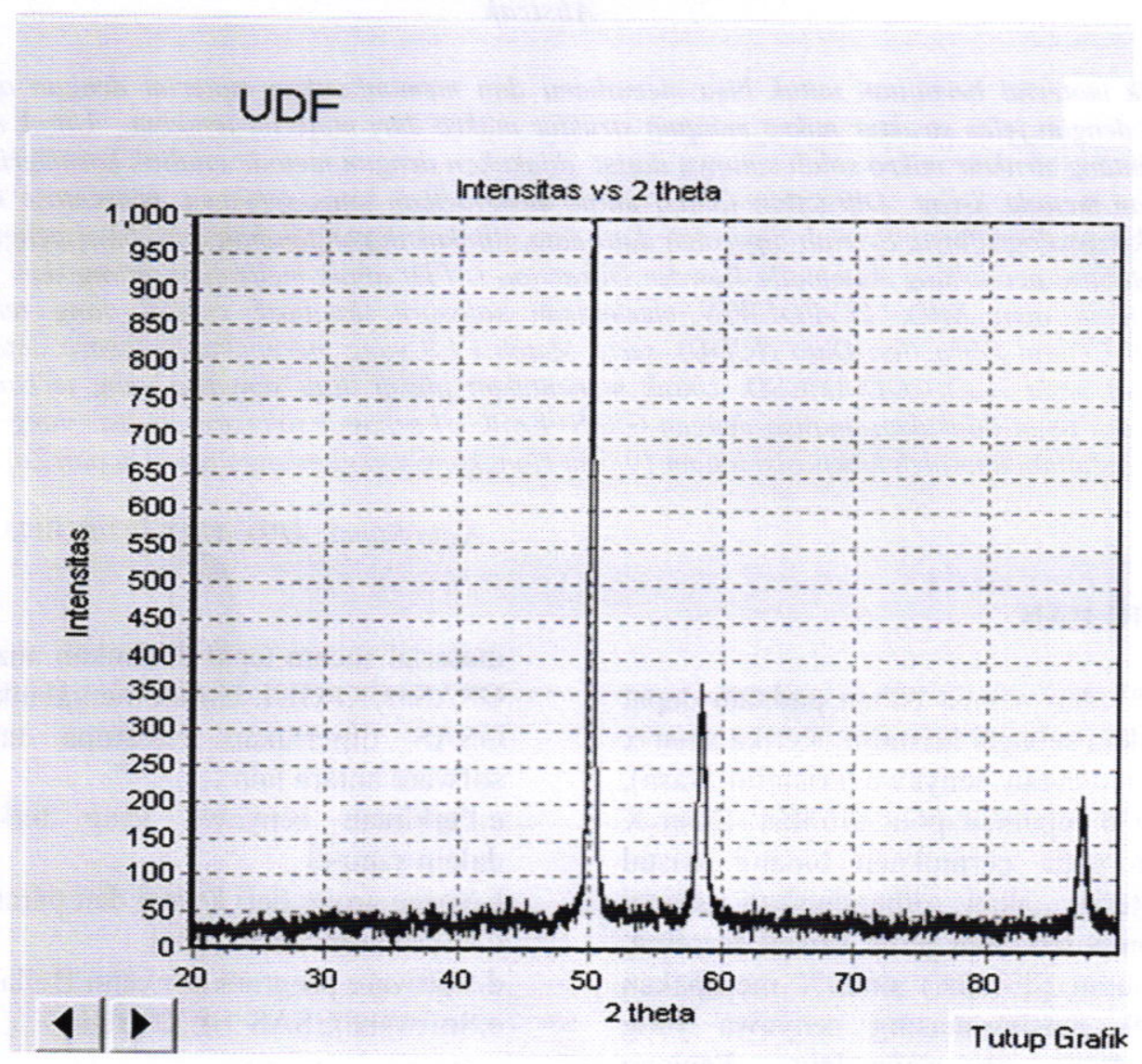

Gambar 1 Pola difraksi XRD yg di reproduksi dg software bella V2_12

\section{Karakterisasi struktur mikro}

Analisa lebih lanjut untuk mengetahui jenis fasa yang terdapat pada sampel, maka data hasil percobaan XRD dengan file exstensi RD dikonversikan ke ekstensi UDF dan UDI dengan menggunakan software APD (Automatic Powder Diffractometer) yang dikeluarkan oleh Phillips (XRD Manufacture).

Langkah selanjutnya adalah melakukan identifikasi fasa pada kristal beserta parameter kisinya dengan berpedoman pada $d$-spacing hasil pengukuran XRD dengan menggunakan software Match versi 1.9. Karena banyaknya data material yang berada di dalam database, maka hasil analisis dengan XRF yang menghasilkan unsur/elemen penyusun kristal pada sampel sangat membantu sekali untuk mempersempit pencarian data.

Proses pencocokan antara data XRD dengan data Match digunakan metode Hanawalt, dimana untuk melakukan identifikasi material yang tidak diketahui melalui identifikasi 3 buah intensitas refleksi tertinggi dan menganggap $d$-spacing dari ketiga intensitas sebagai d1, d2, d3. Jika ketiga nilai d dan intensitasnya mendekati dengan nilai intensitas hasil percobaan, maka dapat dilakukan pencocokan pada semua nilai intensitas dan refleksi yang lainnya. 
Dengan melihat peak position pada pencocokan antara hasil XRD dengan database Match maka dapat diperkirakan fasa yang terkandung dalam paduan solid solution yang dihasilkan mendekati tabel 96-901-3021 untuk $\mathrm{Cu}$ dan 96-900-8523 untuk $\mathrm{Zn}$ di dalam gambar seperti snap shot seperti tersebut di bawah.

\begin{tabular}{|c|c|c|c|c|}
\hline I & Qua. & I Entry I & $x^{3}$ & Nane \\
\hline & C & $96-901-3021$ & $\mathrm{cu}$ & (Copper) \\
\hline & $\varepsilon$ & $96-900-8523$ & $2 \mathrm{n}$ & (Zinc) \\
\hline & $\mathrm{L}$ & * N1 WKa2 & cu & (Coppo) \\
\hline & c & $x \cdot 901-5010$ & cu & (Coppor) \\
\hline & c & $9-901.3023$ & $\mathrm{Cu}$ & (Copper) \\
\hline & C & $x-901-3020$ & $\mathrm{Cu}$ & (CODDer) \\
\hline & 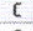 & 96-901-3019 & $\mathrm{Cu}$ & (Copper) \\
\hline & C & $x-901-2436$ & in & (Znc) \\
\hline & c & $x-901-1600$ & in & (Znc) \\
\hline
\end{tabular}

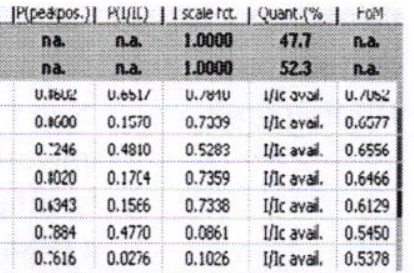

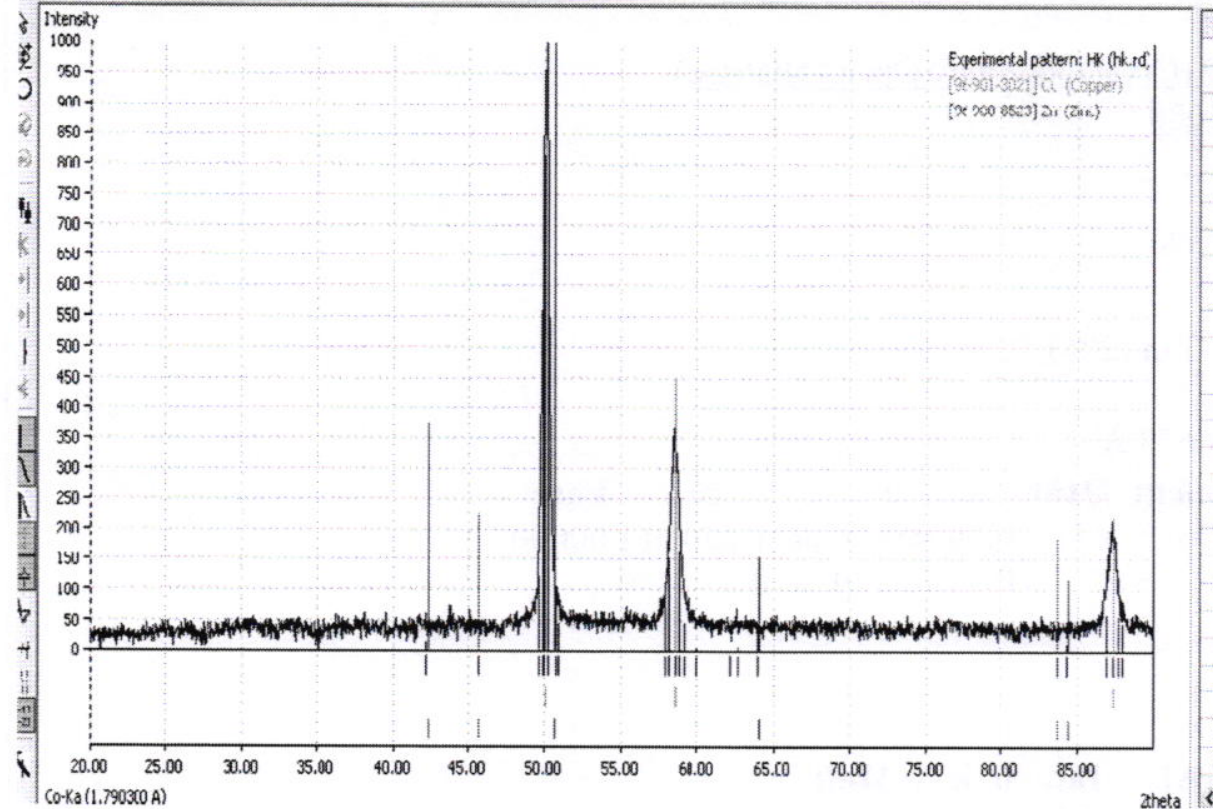

Setelah didapatkan perkiraan jenis fasa yang terkandung di dalam sampel yang disertai juga parameter kisi dan space groupnya dengan bantuan fitting dan pencocokan dengan database, maka untuk memastikan apakah fasa yang terkandung di dalam sampel tersebut memang benar serta untuk menentukan fraksi berat masing-masing fasa tersebut maka perlu dilakukan analisis lebih lanjut lagi dengan menggunakan software GSAS.

Perkiraan senyawa / fasa yang terkandung dalam sampel, space group dan parameter kisi diperoleh dari pencocokan hasil fitting pola difraksi XRD dari sampel dengan Match V1.9, sedangkan posisi atom untuk tiap-tiap fasa yang terkandung dalam sampel diperoleh dari Match seperti tersebut di bawah. 
Tabel 1 Tabel struktur mikro $\mathrm{Cu}$ (sumber AMCSD)

Entry \# 96-901-3021

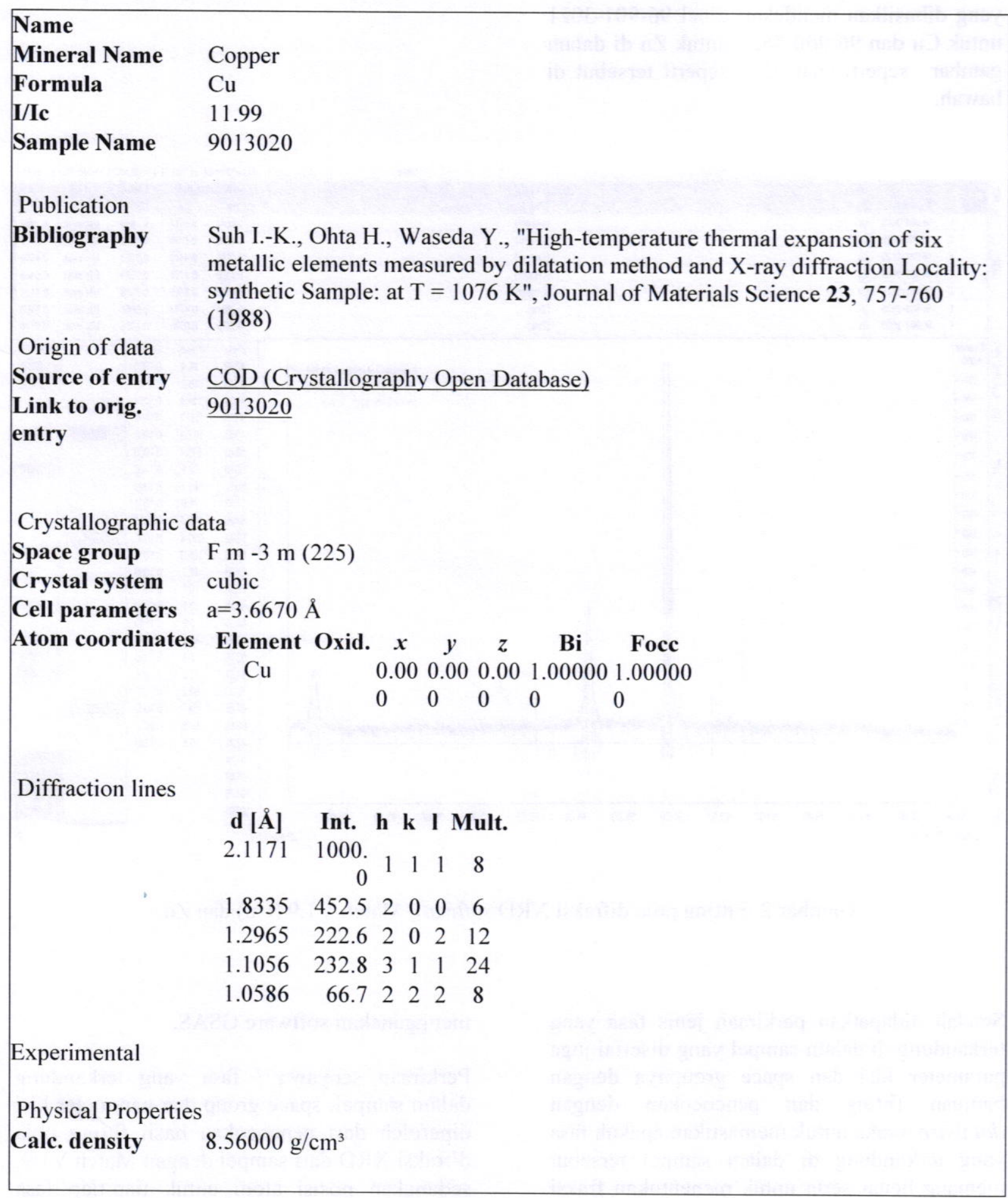


Tabel 2 Tabel struktur mikro Zn (sumber AMCSD)

Entry \# 96-900-8523

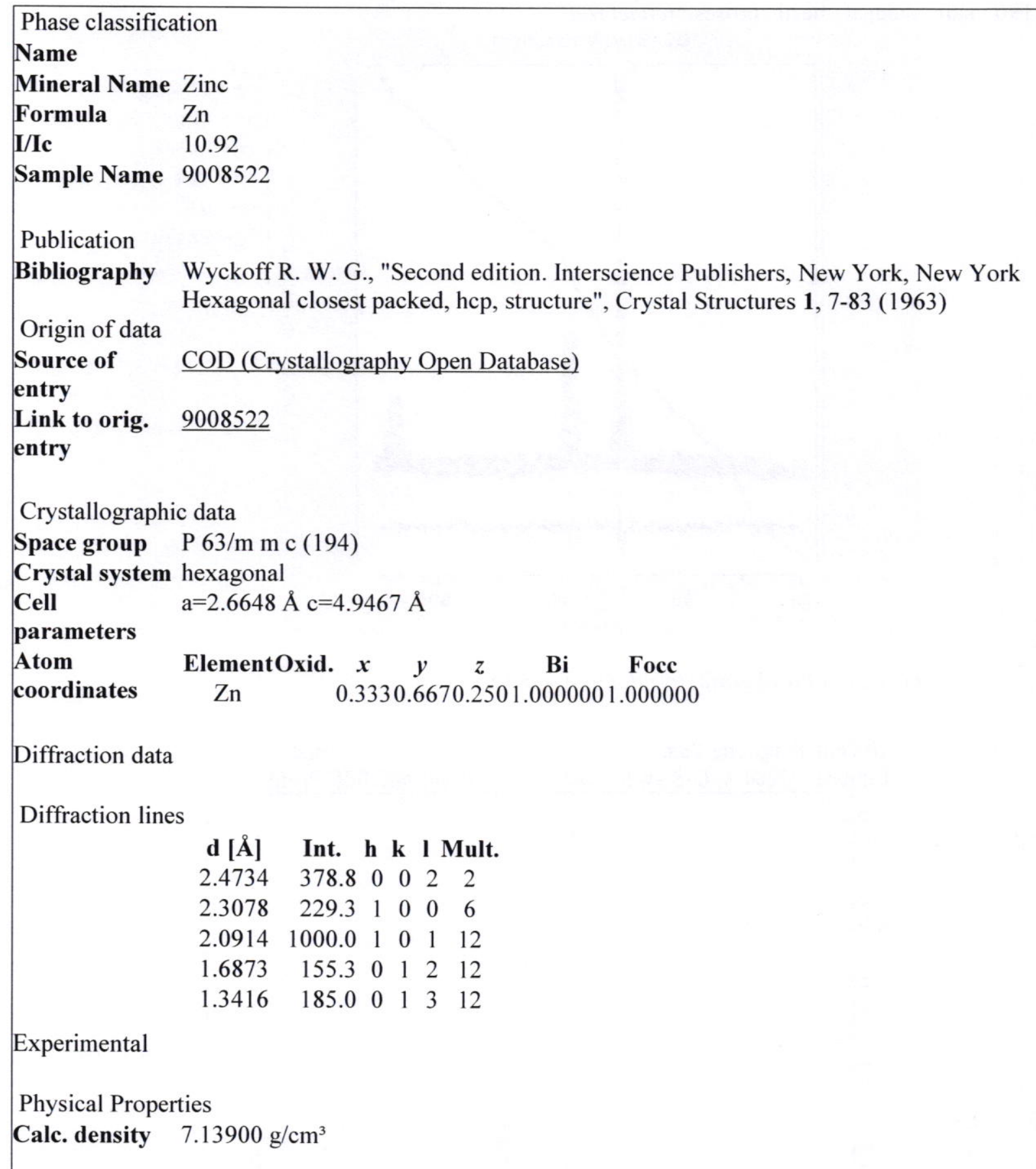

\section{GSAS Refinement}

Jika data-data yang diperlukan untuk menjalankan program GSAS sudah tersedia dan telah dilakukan konversi file percobaan XRD dari extension .udf menjadi extension .raw langkah selanjutnya adalah memasukkan data-data yang diperlukan seperti fasa, elemen, parameter kisi dan posisi atom, dan setelah dimasukkan file percobaan dalam bentuk extension raw serta instrument file dalam extension .prm, maka langkah selanjutnya adalah interasi dengan powpref, powplot dan genless serta perubahan beberapa parameter yang berada di dalam 
program GSAS untuk mendapatkan hasil interasi yang terbaik.

Setelah melakukan iterasi sebanyak

196 kali didapat hasil proses refinement

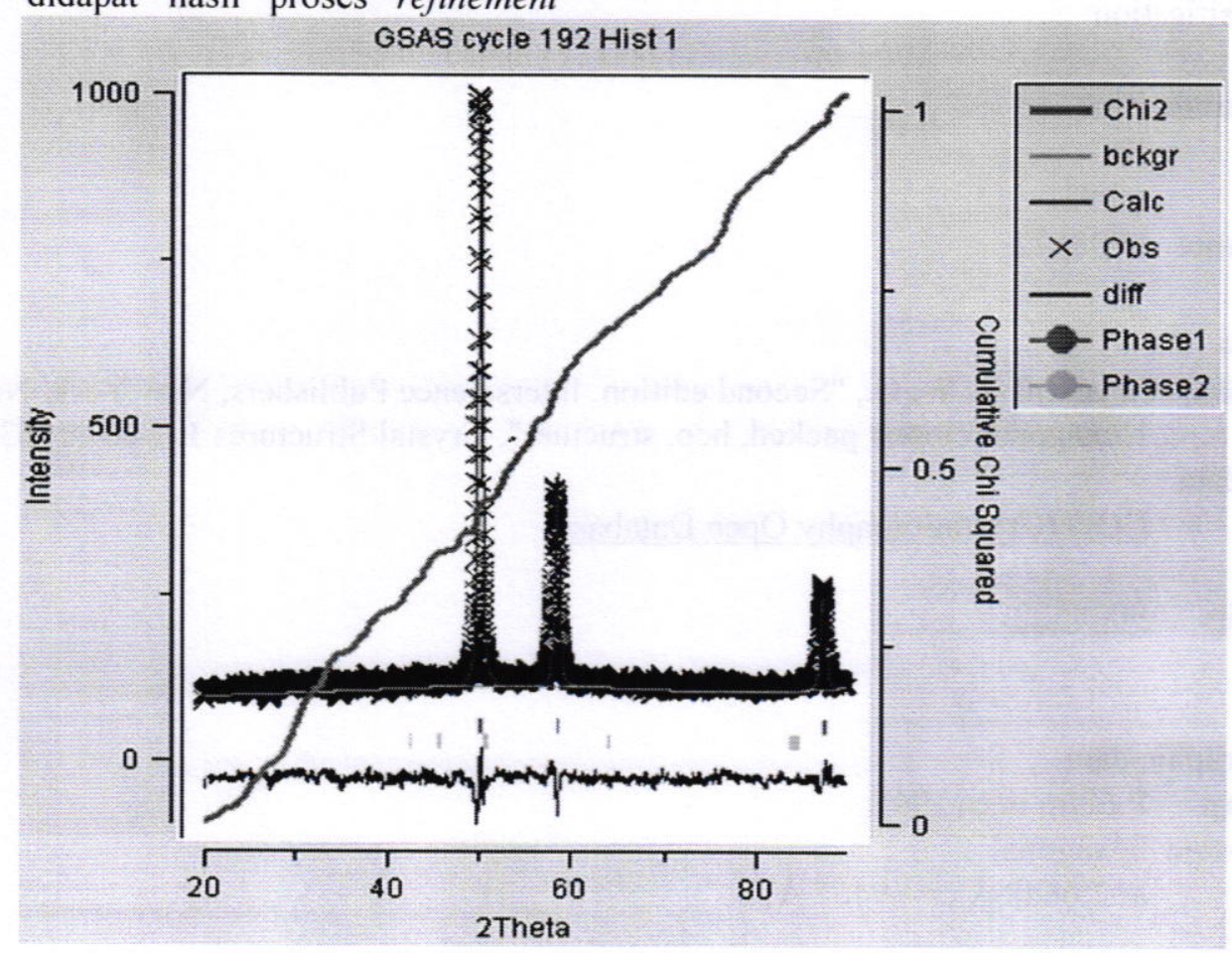

Gambar 3 Profil grafik liveplot hasil GSAS

10 Cent Hongkong Coin Lambda $1.7890 \mathrm{~A}$. L-S cycle 182

Hist 1

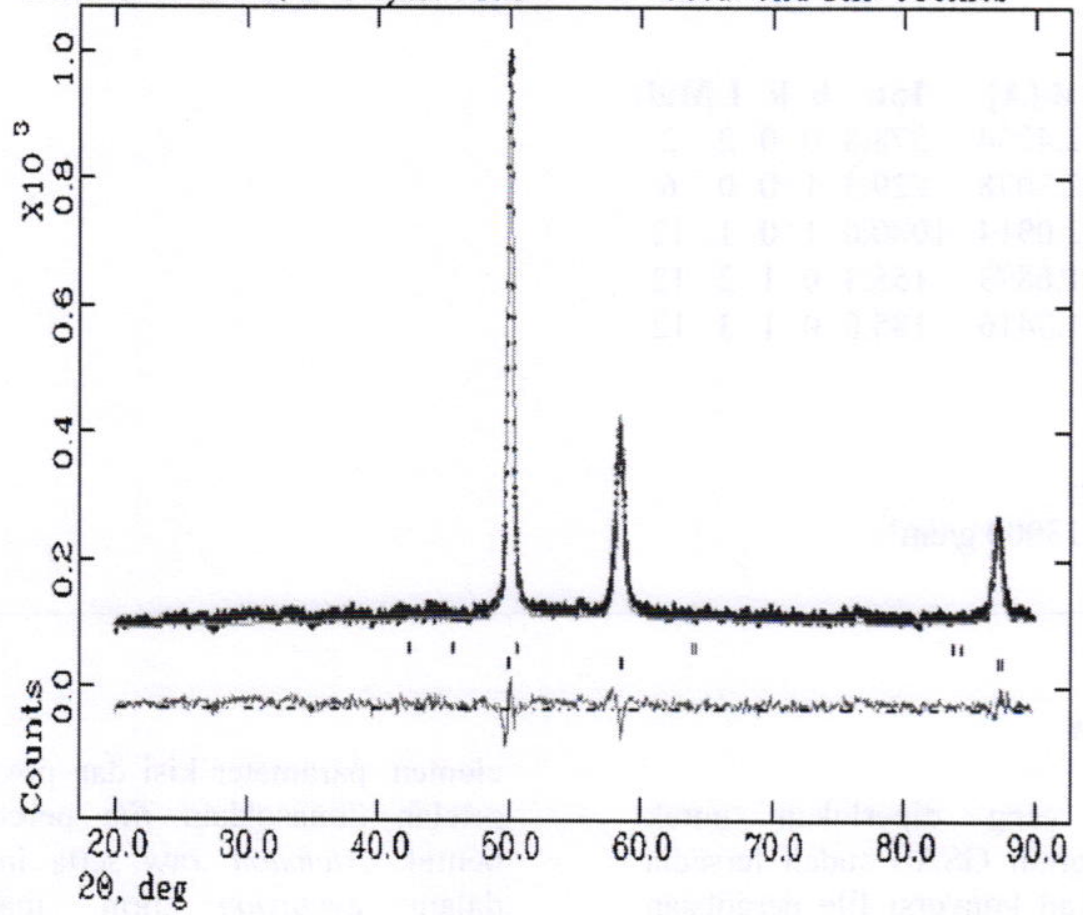

Gambar 4 Profil hasil fitting dengan pola difraksi dengan nilai chi-square dan wRp didapatkan nilai $\mathrm{Chi}^{\wedge} 2=1,024$ dan wRp (weight reduction powder) $\quad=0.0893(8,93 \%)$ 
10 Cent Hongkong Coin

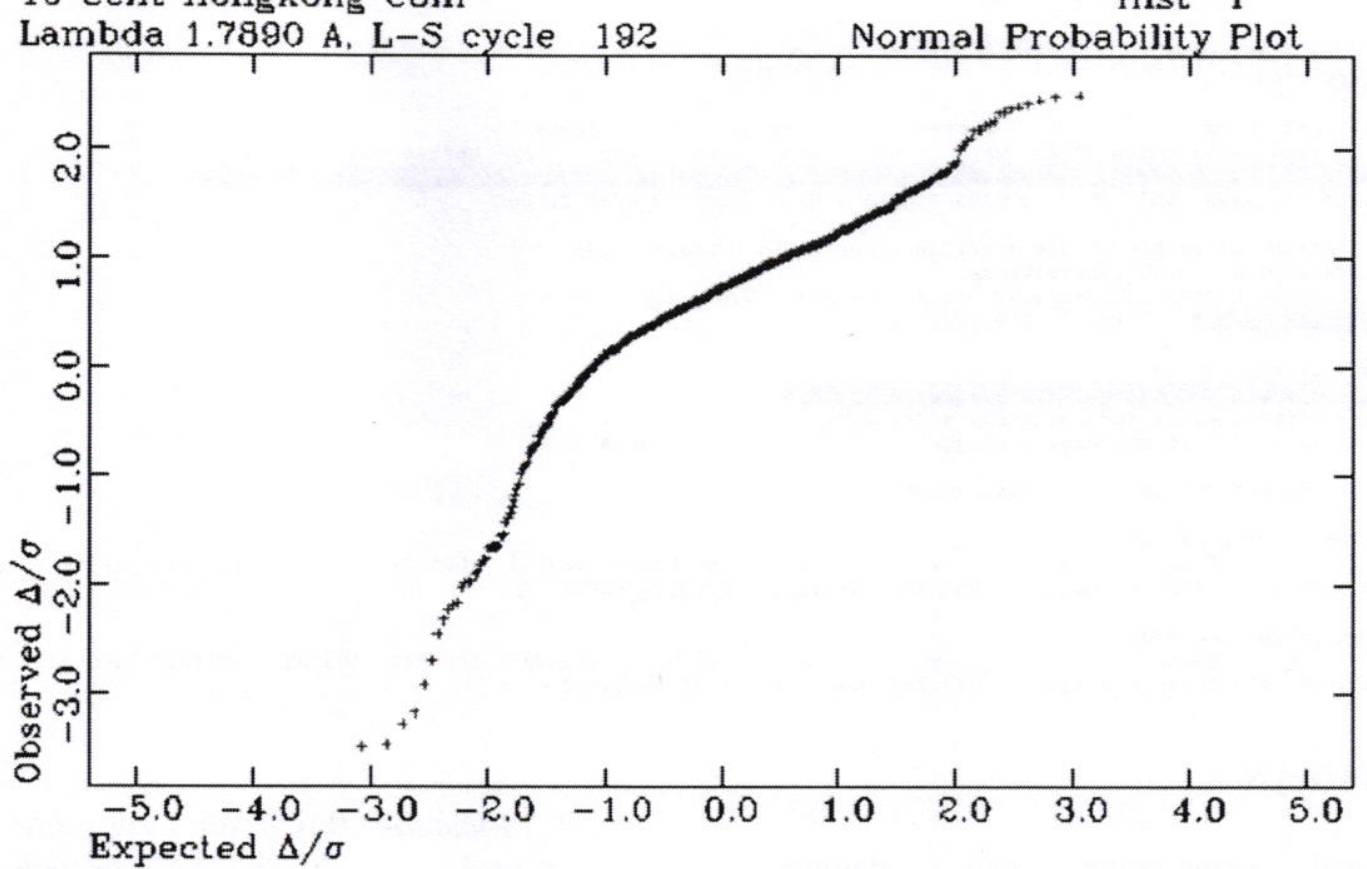

Gambar 5 Profil grafik probability normal

10 Cent Hongkong Coin

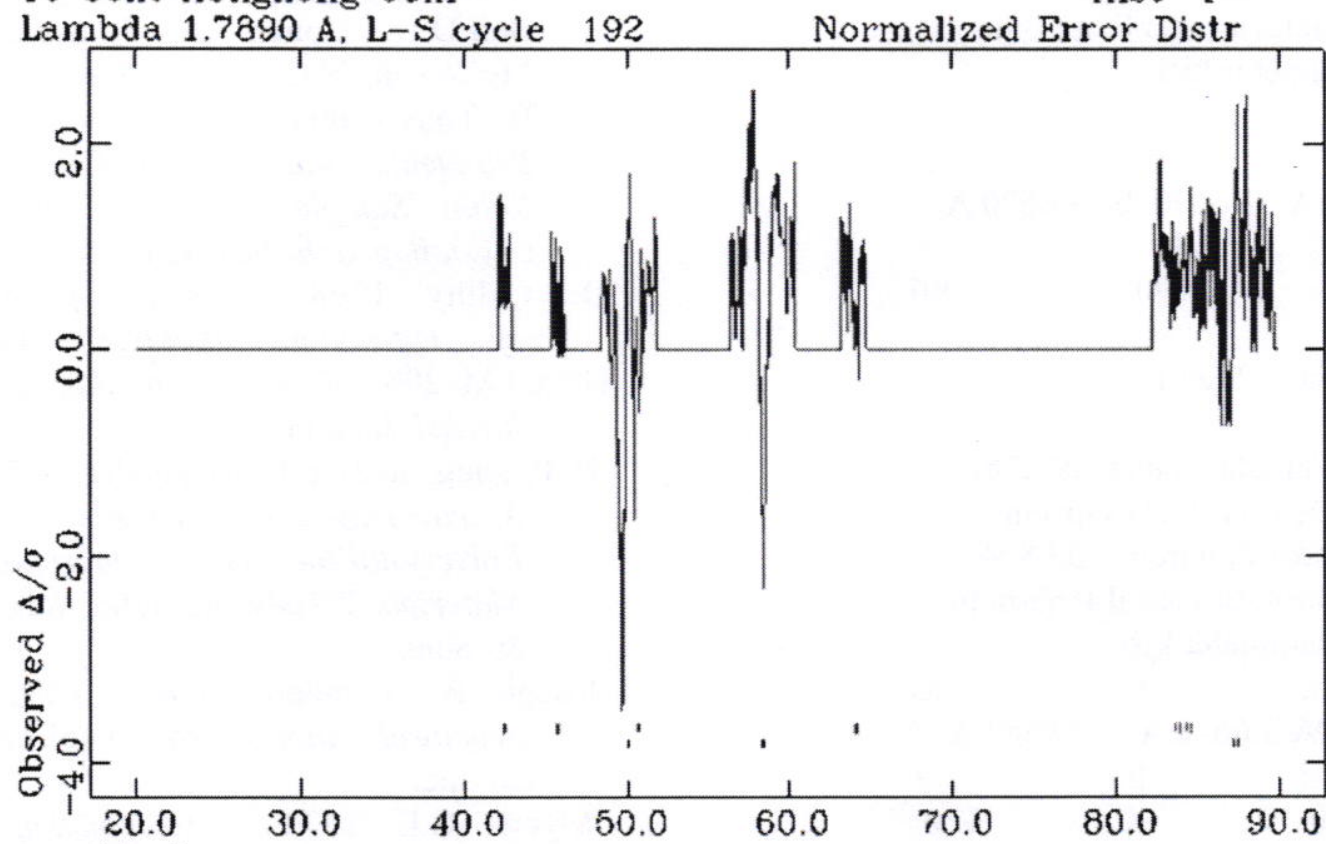

20. deg

Gambar 6 Kurva distribusi kesalahan ternormalisasi 
Tabel 3 Hasil listview fitting dengan GSAS

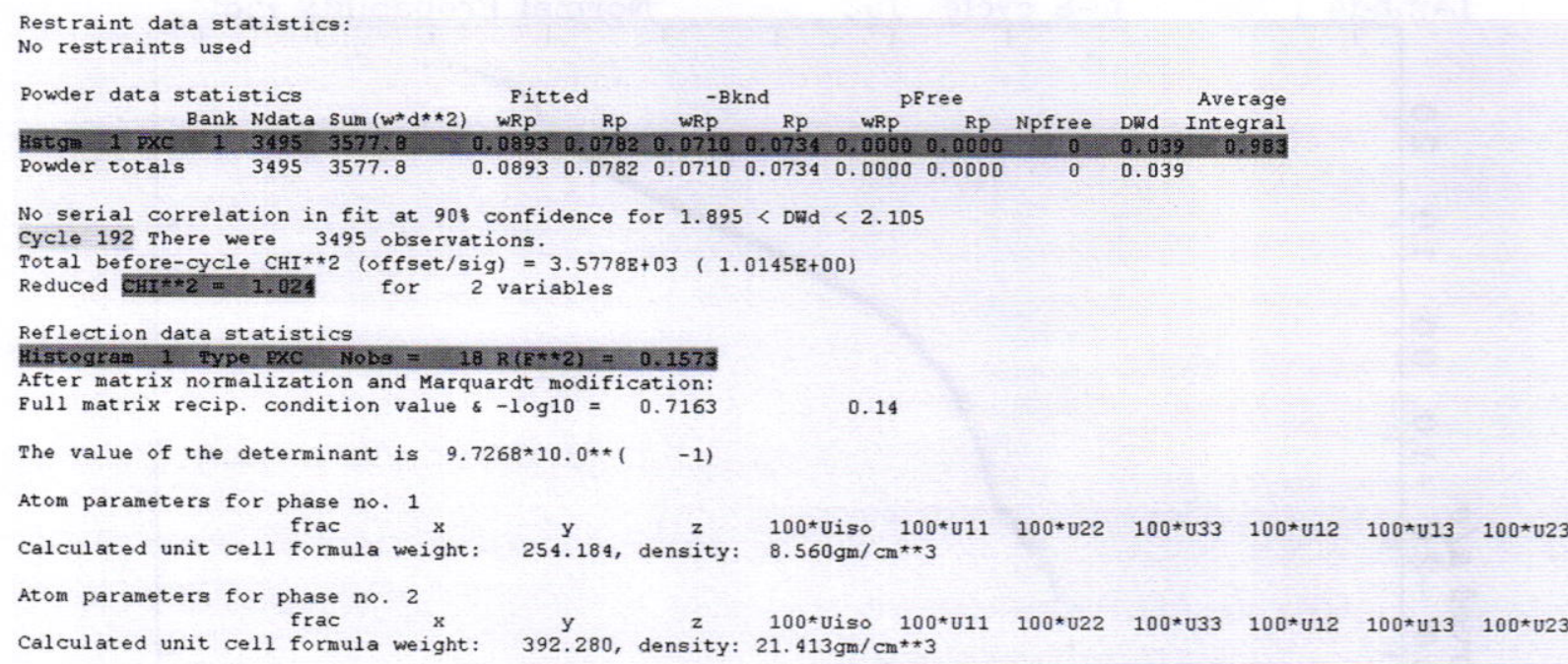

\section{KESIMPULAN}

Dari hasil pengolahan data dengan software GSAS dapat disimpulkan sebagai berikut :

- Fasa-1 (Cu)
a. Calculated ucw 254.184
b. Density $8.560 \mathrm{gm} / \mathrm{cm}^{3}$
c. \%wt Fraction $99.92 \%$
d. Struktur kristal F m -3 m
e. Parameter kisi

$\begin{array}{ccc}\mathrm{a} & \mathrm{b} & \mathrm{c} \\ 3.6670 \AA & 3.6670 \AA & 3.6670 \AA \\ \alpha & \beta & \gamma \\ 90 & 90 & 90\end{array}$

- $\quad$ Fasa-2 (Zn)

a. Calculated ucw 392.28

b. Density $21.413 \mathrm{gr} / \mathrm{cm}^{3}$

c. \%wt Fraction $0.08 \%$

d. Struktur kristal P $63 / \mathrm{m} \mathrm{m}$

e. Parameter kisi

$\begin{array}{ccc}\mathrm{a} & \mathrm{b} & \AA^{\mathrm{c}} \\ 2.6648 \AA & 2.6648 \AA & 4,9467 \AA \\ \alpha & \beta & \gamma \\ 90 & 90 & 120\end{array}$

\section{DAFTAR PUSTAKA}

B. R. York. 1997. New X-ray Diffraction Line Profile
Function Based on Crystallite Size and Strain Distributions Determined from Mean Field Theory and Statistical Mechanics. David Bhartelmy. 2003. Mineralogy Data Base, http:// webmineral. com

D. Balzar, N. Audebrand, M. Daymond, A. Fitch, A. Hewat, J.I. Langford, A. Le Bail,D. Louër, O. Masson, C.N. McCowan, N.C. Popa, P.W. Stephens, B. Toby. 2004. Size - Strain Line Broadenin Analysis of the Ceria Round Robin Sample, Journal of Applied Crystallography 911-924.

D. Cullity. 1998 . Element of $X-$ ray Difraction, Prentice - Hall.

Hikam.M. 2007. Kristalografi dan teknik difraksi. Jakarta

H. P. Klug and L.E. Alexander. 1974. $X$-ray Diffraction Procedures for Polycrystalline and Amorphous Materials, $2^{\text {nd }}$ edition, John Wiley \& Sons.

Joseph B Lambert. 1976 . Organic Structural Analysis, Mc. Publishing Co. Inc.

Myers, G.E. 1972. Conduction Heat Transfer. New York: Mc.Graw-Hill Book Company.

S. Enzo, G. Fagherazzi, A. Benedetti,

S. Polizzi . 1988 . A Profile-Fitting Procedure for Analysis of Broadened X-ray Diffraction, $J$. Appl. Cryst. 21,536-542. 